Carlos Acufia

\title{
Motivos de la espiga
}

\section{LAS ESPIGAS VERDES}

RAS de los cercados, cada espiga verde es una divina promesa de mies: se yergue bizarra, si el viento la muerde, mas con la luna es humilde a la vez.

Amo estas espigas esbeltas; se pierde la vista en millares: del campo un pavés... Son así tan jóvenes para que recuerde que mi juventud va a la madurez.

Estas cañas ágiles que anuncian el grano como nuestras vidas, no otra cosa son: de la primavera sólo hasta el verano

dura, bajo el cielo, su alegre canción. ¿Después? Corre el tiempo, y una torva mano las desgrana en lágrimas como a un corazón. 


\section{LA ESPIGA DE LA SIEGA}

Tiempo era de la siega

y dejaste morirse las espigas:

se desgranaron todas en la tierra.

Yo me quedé perdido

como un labriego ávido ante el surco.

Vino el viento y la lluvia,

y lo deshizo todo:

ni una semilla en flores se ha cuajado.

El tiempo

rasó la sementera.

Alguna vez asciende

un vilano del cardo, y sube, y sube como una araña blanca...

Yo, encorvado en la tierra,

sé que habrá de caer en otro surco;

mas no será aquel grano de la espiga bella y dorada de mi amor; tan sólo un sueño de aquel sueño...

ITú las dejaste todas desgranarse:

espigas del amor que hiciste estérill 